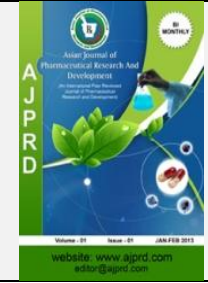

Open $\odot$ Access

\title{
Phytochemical Screening and Assesment of Bioactivity of Pagoda Flower (Clerodendrum paniculatum L.) Using Brine Shrimp (Artemia salina) Lethality Assay
}

\section{Hafiz Ihsanul *, Fitri Khairani, Sipayung Joi Helvin}

Faculty of Pharmacy and Health, Institut Kesehatan Helvetia, Kapten Sumarsono Street 107, Medan, Sumatera Utara, Indonesia

\section{A B S T R A C T}

\section{ABSTRACT}

Objectives: The purpose of this study was to determine the bioactive content of the pagoda flower ethanol extract and measure its activity using the brine shrimp lethal dose method

Design: The design of this study was qualitative and quantitative experimental, where bioactive compounds of pagoda flower ethanol extract were tested by qualitative chemical analysis and brine shrimp lethal dose method was quantitatively calculated the number of deaths.

Interventions: The variable that was intervened in this study was the concentration of extract used.

Main outcome measure: The main measurement results in this study were to know the bioactive compounds contained in the extract and the value of Lethality Concentration $50 \%\left(\mathrm{LC}_{50}\right)$.

Results: The results of phytochemical screening from the ethanol extract of pagoda flowers showed bioactive compounds such as alkaloids, flavonoids, steroids/triterpenoids, tannins, saponins, and glycosides. The value of $\mathrm{LC}_{50}$ in the toxicity test for artemia salina was $49.415 \mathrm{ppm}$.

Conclusion: The pagoda flower ethanol extract contains alkaloid compounds, flavonoids, steroids/triterpenoids, tannins, saponins, and glycosides. Pagoda flower ethanol extract has strong potential activity.

Keywords: Clerodendrum paniculatum L., secondary metabolites, lethality concentration 50

A R T I C L E I N F 0: Received 26 April 2019; Review Completed 22 May 2019; Accepted 08 June 2019; Available online 15 June 2019

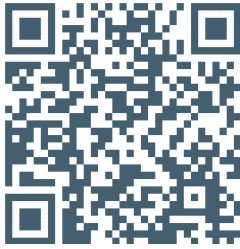

Cite this article as:

Hafiz Ihsanul*, Khairani Fitri, Joi Helvin Sipayung, Phytochemical Screening and Assesment of Bioactivity of Pagoda Flower (Clerodendrum paniculatum L.) Using Brine Shrimp (Artemia salina) Lethality Assay, Asian Journal of Pharmaceutical Research and Development. 2019; 7(3):10-13, DOI: http://dx.doi.org/10.22270/ajprd.v7i3.527

*Address for Correspondence:

Ihsanul Hafiz, Faculty of Pharmacy and Health, Institute Kesehatan Helvetia, Kapten Sumaarsono Street 107, Medan, Sumatera Utara, Indonesia

\section{INTRODUCTION}

$\mathrm{T}$ he pagoda flower (Clerodendrum paniculatum L.) is a plant with the genus Clerodendrum which has 580 species variations spread across the continents of Asia, Africa, America and Australia. This plant is traditionally used as a medicine in Asia and Africa, including China, India, Korea, Thailand, Japan and Indonesia $^{1}$. The several studies that have been carried out on these types of plants include; anti-inflammatory activity $^{2}$, testing antibacterial activity in C. paniculatum ${ }^{3}$, anti-hepatotoxic activity in $\mathrm{C}$. inerme ${ }^{4}$, hypotensive effects of C. phlomidis ${ }^{5}$, antidiabetic, antihypertensive and sedative C. phlomidis and C. mandarinorum ${ }^{1}$.

The amount of research on pagoda flowers is the basis for bioactive screening and measurement of activity potential through toxicity testing using the brine shrimp bioassay method.

MATERIALS AND METHODS

ISSN: 2320-4850

\section{Plant and Chemicals Materials}

The pagoda used in this study was obtained from the Pancur Batu area in Deli Serdang Regency, North Sumatra, Indonesia. The part of the plant used is flowers. Pagoda flowers have been determined by the Herbarium Bogoriense Indonesian Institute of Science and it is known that the species is Clerodendrum paniculatum $\mathrm{L}$. with Familia Lamiaceae.

The apparatus used in this study were mortar and pestle, sieves, maceration containers, analytical scales, aluminum foil, whatmann filter paper, spatulas, measuring cups, measuring flasks, beaker glass, test tubes, volume pipettes, rubber balls, water bath, and rotary evaporator.

The cchemicals used in this study were ethanol, $n$-hexane, ether, $\mathrm{H}_{2} \mathrm{SO}_{4}, \mathrm{HCl}$, amyl alcohol, isopropanol, $\mathrm{CHCl}_{3}$, methanol, were obtained from Merck. Mayer, Dragendorff, Bouchardat, Liebermann-Burchard reagent, 
Molisch reagent, Lead (II) acetate, $\mathrm{Mg}$ powder, $\mathrm{FeCl}_{3}$ and dimethyl solfoxide (DMSO).

\section{Preparation of Ethanol Extract}

Harvested pagodas are dried using a drying cupboard at $40^{\circ} \mathrm{C}$ for three days. The dried part of the plant is called simplicia. Simplicia which has been deemed dry and can be continued to be extracted is simplicia containing water content below 10\%. Simplicia is then pollinated, then macerated using $96 \%$ ethanol for three days. The extract solution from the pagoda flower is separated from the pulp. The extract was then dried using a rotary evaporator until a thick extract was obtained ${ }^{6}$.

\section{Phytochemical Screening}

\section{Identification of Alkaloids}

The ethanol extract $(500 \mathrm{mg})$ was divided into 3 test tubes. Afterward, the tubes were added with one $\mathrm{mL}$ of hydrochloric acid $2 \mathrm{~N}$ and $9 \mathrm{~mL}$ of water, respectively. Next, heated over a water bath for 2 minutes, then cooled and strained. Then added to each tube 2 drops of Meyer, Bouchardat and Dragendorff reagents ${ }^{7,8}$.

\section{Identification of Flavonoids}

The ethanol extract $(500 \mathrm{mg})$ was divided into 2 test tubes. After that, the tubes were added with $10 \mathrm{~mL}$ of methanol, respectively. Next, refluxed using a cooler for 10 minutes. Filtered heat through multiple filter paper, diluted with $10 \mathrm{~mL}$ of distilled water. After cold, $5 \mathrm{~mL}$ of ether was added, stirring carefully, then let stand. The methanol layer is taken, evaporated at $40^{\circ} \mathrm{C}$ under pressure. the extract obtained was dissolved in $5 \mathrm{~mL}$ of ethyl acetate ${ }^{7,8}$.

The extract in the first tube was evaporated to dryness, then dissolved in $2 \mathrm{~mL}$ of $96 \%$ ethanol, added $0.5 \mathrm{~g}$ of zinc powder and $2 \mathrm{~mL}$ of $2 \mathrm{~N}$ hydrochloric acid, left for 1 minute. Added 10 drops of concentrated hydrochloric acid, if within 2 to 5 minutes there is an intense red color indicating the presence of flavonoids (glycoside-3flavonol) ${ }^{7,8}$. The extract in the second tube was evaporated to dryness, dissolved in $1 \mathrm{~mL}$ of $96 \%$ ethanol, added $100 \mathrm{mg}$ of magnesium powder and $10 \mathrm{~mL}$ of concentrated $\mathrm{HCl}$, if red orange was formed until the red purple color indicated the presence of flavonoids. If orange yellow is formed, indicates the presence of flavones and chalcons ${ }^{7,8}$.

\section{Identification of Glycosides}

The ethanol extract $(3 \mathrm{~g})$ was putted into the erlenmeyer, then added $30 \mathrm{~mL}$ of the mixture of $90 \%$ ethanol $(7: 3)$, concentrated sulfuric acid was added until the $\mathrm{pH}$ of solution 2 was obtained, then refluxed by using a ball cooler for 10 minutes, then cooled, then filtered. After that, $20 \mathrm{~mL}$ of filtrate was taken, and then $25 \mathrm{~mL}$ of water and $25 \mathrm{~mL}$ of lead (II) acetate $0.4 \mathrm{M}$ were added. Next, shaked and left for 5 minutes, then filtered. The filtrate was extracted 3 times with $20 \mathrm{~m} / \mathrm{L}$ of a solvent mixture of chlofororm: isopropanol $(3: 2)$, then two layers were obtained. In extracting, each organic solvent sodium sulfate anhydrous was added and filtered. Afterward, the filtrate was evaporated at no more than $50^{\circ} \mathrm{C}$, then the residue was dissolved in $2 \mathrm{~mL}$ of methanol, then divided into 3 test tubes ${ }^{7,8}$.
The extract in the first tube was boiled in water and added a Liebermann-Burchard reagent, then a blue or green color was occurred that indicating the presence of glycosides $^{7,8}$.

The third tube of sample was boiled in water, then cooled and filtered. After that, added a lot of Fehling A and Fehling B solution and heated, then a red brick precipitate was formed that exhibit the presence of reducing sugar ${ }^{7,8}$.

The extract in the second tube was evaporated over a water bath then added $2 \mathrm{~mL}$ of water and 5 drops of Molish reagent. Next, added $2 \mathrm{~mL}$ of concentrated sulfuric acid, then a purple ring was formed at the fluid boundary that indicating a sugar bond ${ }^{7,8}$.

\section{Identification of Saponins}

The ethanol extract $(500 \mathrm{mg})$ was putted into a test tube. After that, $10 \mathrm{~mL}$ of hot water was added, then cooled and shaked with vigorously for 10 seconds. If the compound was examined in the form of a liquid preparation, diluted $1 \mathrm{~mL}$ of that liquid preparation with $10 \mathrm{~mL}$ of distilled water and shaked vigorously for 10 minutes. A positive result was exhibited with a constant froth for no less than 10 minutes, as high as $1 \mathrm{~cm}$ to $10 \mathrm{~cm}$ then by addition 1 drops of $\mathrm{HCl} 2 \mathrm{~N}$, the froth was not disappear ${ }^{7,8}$.

\section{Identification of Tannins}

The ethanol extract $(500 \mathrm{mg})$ was extracted with $10 \mathrm{~mL}$ of distilled water for 15 minutes. Then filtered, the filtrates were diluted with distilled water until they were almost colorless. Taken $2 \mathrm{~mL}$ of filtrate, and then added 2 drops of $10 \% \mathrm{FeCl}_{3}$ solution. Note the color that occurs, blue or green indicates tannin, blue indicates 2 hydroxy groups in the aromatic ring of tannin ${ }^{7,8}$.

\section{Identification of Steroids and Terpenoids}

The ethanol extract (1g) was added with ether or $n$ hexane, let stand for 2 hours, then filtered. Next, the filtrate was evaporated. The result of extraction was added anhydride acetic acid, then pressed concentrated sulfuric acid (Liebermann-Bouchardart reagent). Occurrence of red or red or turn blue green indicates a triterpenoids and steroids $^{7,8}$.

\section{Brine Shrimp Lethality Bioassay}

Preparation of Artemia salina by $1 \mathrm{~g}$ of egg is placed in a container containing salt water, left for 1-2 hours. After that, the soaked eggs are transferred into $2 \mathrm{~L}$ of salt water to drop. When hatching eggs for 2 days, during the hatching process they are illuminated with 40-60 watt incandescent light so that the hatching temperature is maintained. The test solution was made with concentrations of 20,40, 60, 80 and 100 ppm in DMSO (dimethyl sulfoxide) and aquadest solvents. For the negative control, DMSO and aquadest solvents were used without extract $(0 \%)$. All test solutions are prepared in a test tube. Each tube is inserted into 10 Artemia salina larvae, leave for 24 hours, then observe and count the number of larval deaths in each test tube ${ }^{9,10}$. Based on the number of deaths of Artemia salina in each group, the value of lethality concentration of $50 \% \quad\left(\mathrm{LC}_{50}\right)$ was calculated using the probit analysis method. 


\section{RESULTS AND DISCUSSION}

\section{Results}

The results of the research presented below are the results of a qualitative analysis of the bioactive content of the pagoda flower ethanol extract. The test results of the bioactive potential of pagoda flower ethanol extract are presented in a table that shows the average brine shrimp mortality value per concentration, then the number of deaths from each of these concentrations was calculated $\mathrm{LC}_{50}$ value by means of probit analysis using SPSS program. The results of the identification of bioactive ethanol extract of pagoda flowers can be seen in table 1 .
Table 1: The results of phytochemical screening of ethanol extract of pagoda flowers

\begin{tabular}{|l|l|l|}
\hline No & Bioactives & Result \\
\hline 1 & Alkaloids & + \\
\hline 2 & Flavonoids & + \\
\hline 3 & Steroids/Triterpenoids & + \\
\hline 4 & Tannins & + \\
\hline 5 & Saponins & + \\
\hline 6 & Glycosides & + \\
\hline
\end{tabular}

Table 2: The results of the test of brine shrimp lethality

\begin{tabular}{|l|l|l|}
\hline No & Groups & $\begin{array}{l}\text { Average of Lethality } \\
\text { Values } \pm \text { Standard Error }\end{array}$ \\
\hline 1 & Control $(0 \mathrm{ppm})$ & $0.00 \pm 0.00$ \\
\hline 2 & $20 \mathrm{ppm}$ & $1.33 \pm 0.33$ \\
\hline 3 & $40 \mathrm{ppm}$ & $4.67 \pm 0.33$ \\
\hline 4 & $60 \mathrm{ppm}$ & $6.33 \pm 0.33$ \\
\hline 5 & $80 \mathrm{ppm}$ & $7.00 \pm 0.00$ \\
\hline 6 & $100 \mathrm{ppm}$ & $9.67 \underline{ \pm 0.33}$ \\
\hline
\end{tabular}

The $\mathrm{LC}_{50}$ value based on probit analysis using the SPSS program can be seen in table 3 .

Table 3: The $\mathrm{LC}_{50}$ value based on probit analysis

\begin{tabular}{|l|l|l|}
\hline Probability & $\begin{array}{l}\text { 95\% Confidence Limits for } \\
\text { Concentrations }\end{array}$ & $\begin{array}{l}\text { 95\% Confidence Limits for log } \\
\text { Concentrations) }\end{array}$ \\
\hline & Estimate & Estimate \\
\hline 0.100 & 18.036 & 1.256 \\
\hline 0.200 & 24.777 & 1.394 \\
\hline 0.300 & 31.153 & 1.493 \\
\hline 0.400 & 37.885 & 1.578 \\
\hline $\mathbf{0 . 5 0 0}$ & $\mathbf{4 5 . 4 8 7}$ & $\mathbf{1 . 6 5 8}$ \\
\hline 0.600 & 54.615 & 1.737 \\
\hline 0.700 & 66.418 & 1.822 \\
\hline 0.800 & 83.508 & 1.922 \\
\hline 0.900 & 114.721 & 2.060 \\
\hline
\end{tabular}

\section{Discussions}

Research that has been done on the largest chemical composition of the genus Clerodendrum was steroids, such as: $\beta$-sitosterol, $\gamma$-sitoterol octacosanol, clerosterol, bungein A, acteoside, betulinic acid, clerosterol 3-O- $\beta$ Dglucopyranoside, colebrin AE, campesterol , $4 \alpha-$ methylsterol, cholesta- 5-22-25-trien-3- $\beta$-ol, 24- $\beta$ cholesta-5-22-25-trine, cholestanol, 24-methyl-22dihydrocholestanol, 24- $\beta$ - 22 -25-bis-dehydrochlesterol, 24-a-methyl-22-dehydrocholesterol, 24- $\beta$-methyl-22dehydrocholesterol, 24-ethyl-22-dehydrocholesterol, 24ethylcholesterol, 22-dehydroclerosterol, 24methyllathosterol, 24- $\beta$-ethyl-25-dehydrolathosterol, (24S) -ethylcholesta-5-22-25-triene-3 $\beta$-ol which has been isolated from various species of Clerodendrum such as C.inerme, C. phlomidis, C. infortunatum, C. paniculatum, C cyrtophyllum, C. fragrans, C. splendens, C. campbellii and C. splendens ${ }^{1}$.

Other content is terpen compounds, including monoterpenes, diterpenes, triterpenes, iridoids and sesquiterpenes. The flavonoids found in the genus Clerodendrum include cynaroside, 5-hydroxy-4'-7dimethoxymethyl flavone, kaempferol, salvigenin, 4methyl scutellarein, 5,7,4 O-trihydroxyflavone, apigenin, luteolin, acacetin-7 -O-glucuronide, Hispidulin, 2'-44'trihydroxy-6'methylchalcone, 7-hydroxy flavone, and others. The glycosides contained in Clerodendrum are cyanogenic glycosides such as lucumin and prunasin ${ }^{1}$.

Based on the probit analysis of the number of brine shrimp deaths carried out, the LC50 value of the ethanol extract of the pagoda flower (Clerodendrum paniculatum L.) was $45,487 \mathrm{ppm}$. The same study was conducted by Waliullah et al in 2015 on ethanol and chloroform extract from roots, leaves and stems of Clerodendrum infortunatum Linn. The results showed that $\mathrm{LC}_{50}$ values of ethanol extract from roots, leaves and stems were 20,845, 24,017 and 31,379 ppm, LC $_{50}$ values of chloroform extract were $30,702,32,907$ and 42,559 $\mathrm{ppm}^{11}$.

The evaluation of the toxic action of plant extracts is indispensable in order to consider a treatment safe; it enables the definition of the intrinsic toxicity of the plant and the effects of acute overdose ${ }^{12,13}$. The procedure was adopted to determine the lethality of crude plant extracts to brine shrimp. Artemia bioassay has been demonstrated to provide a viable alternative to the mouse bioassay, which is expensive and associated with ethical constraints. In bioactivity evaluation of plant extracts by brine shrimp bioassay, an $\mathrm{LC}_{50}$ value lower than $1000 \mathrm{ppm}$ is considered cytotoxic ${ }^{14,15}$. 


\section{CONCLUSSION}

The pagoda flower ethanol extract contains alkaloid compounds, flavonoids, steroids/triterpenoids, tannins, saponins, and glycosides. Pagoda flower ethanol extract has strong potential activity.

\section{REFERENCES}

1. Shrivastava N, Patel T. Clerodendrum and Heathcare: An Overview. Medicinal and Aromatic Plant Science and Biotechnology, MAPSB. 2007; 1(1):14-150.

2. Hafiz I, Rosidah, Silalahi J. Antioxidant and Anti-Inflammatory Activity of Pagoda Leaves (Clerodendrum Paniculatum 1.) Ethanolic Extract in White Male Rats (Rattus Novergicus), International Journal of PharmTech Research. 2016; 9(5):165-170.

3. Joseph J, AR B, Aleykutty N. Antimicrobial activity of Clerodendrum paniculatum Linn Leaves. International Journal of Research in Ayurveda and Pharmacy. 2011; 2(3):1003-1004.

4. Verma A, Ahmed B. Anti-Hepatotoxic Activity of Clerodendrum Phlomidis. International Journal of Pharm Tech Research. 2009; 1(4): 1028-1031.

5. Guessan K, Zirihi G, Mea A. Hypotensive Effect of Aqueous Extract of Clerodendrum Inerme Leaves on the Arterial Pressure of Rabbits. Int J Pharm Biomed Res. 2010; 1(2):73-77.

6. Azwanida, NN. A Review on the Extraction Methods Use in Medicinal Plants, Principle, Strength and Limitation. Medicinal \& Aromatic Plants. 2015; 4(3):1-6.

7. Health Department of Republic of Indonesia. Materia Medika Indonesia. 5th ed. Jakarta: Dirjen POM; 1989:153-171

8. Farnsworth NR. Biological and Phytochemical Screening of Plants. J Pharm Sci. 1966; 55(3):225-276

9. Krishnarajua AV, Raoa TVN, Sundararajua D, Vanisreeb M Assessment of Bioactivity of Indian Medicinal Plants Using Brine

\section{ACKNOELEDGEMENTS}

The author are thank full to Yayasan Helvetia, Institut Kesehatan Helvetia for valuable support and providing facilities to carry out this research work.

10. Shrimp (Artemiasalina) Lethality Assay. International Journal of Applied Science and Engineering. 2005; 3(2):125-134.

11. Carballo JL, Hernández-Inda ZL, Pérez P, García-Grávalos MD. A comparison Between Two Brine Shrimp Assays to Detect In Vitro Cytotoxicity in Marine Natural Products. BMC Biotechnology. 2002; 2(17):1-5

12. Waliullah TM, Yeasmin AM, Alam AM, Islam WM, Hassan P Estimation of Cytotoxic Potency by Brine Shrimp Lethality Bioassay Application of Clerodendrum infortunatum Linn. Journal of Coastal Life Medicine. 2015; 3(8):636-639.

13. Padmaja R, Arun P, Prashanth D, Deeepak M, Amit A, Anjana M. Brine Shrimp Lethality Bioassay of Selected Indian Medicinal Plants. Fitoterapi, 2002; 73(6):508-510.

14. Ngutaa J, Mbariaa J, Gakuyab D, Gathumbic P, Kabasad J, Kiama S. Evaluation of Acute Toxicity of Crude Plant Extracts from Kenyan Biodi-versity using Brine Shrimp, Artemia salina L. (Artemiidae). The Open Conference Proceedings Journal, 2012 2012(3):30-34

15. Kohler I, Jennet-Siems K, Kraft C, Siems K, Abbiw D, Bien-zle U, et al. Herbal Remedies Traditionally Used Against Malaria in Ghana: Bioassay Guided Fractination of Microglossa pyrifolia (Asteraceae). Z. Naturforsch. C. 2002; 2002(57):1022-1027.

16. Krishnaraju A, Rao T, Sundaraju D, Vanisree M, Tsay H, Subbaraju. Biological Screening of Medicinal Plants Collected from Eastern Ghats of India using Artemia Salina (Brine Shrimp Test). Int. J. Appl. Sci. Eng, 2006; 4(2):115-125. 